\title{
COVID-19 Impacts on Rubber Farmers in Thailand: A Study of Behavioral Change and Livelihoods
}

\author{
Chaiya Kongmanee, Ferdoushi Ahmed* \\ Faculty of Economics, Prince of Songkla University (PSU), Hat Yai, Songkhla, 90112, Thailand
}

Received October 3, 2021; Revised November 26, 2021; Accepted December 22, 2021

\begin{abstract}
Cite This Paper in the following Citation Styles
(a): [1] Chaiya Kongmanee, Ferdoushi Ahmed, "COVID-19 Impacts on Rubber Farmers in Thailand: A Study of Behavioral Change and Livelihoods," Universal Journal of Agricultural Research, Vol. 9, No. 6, pp. 277 - 288, 2021. DOI: 10.13189/ujar.2021.090606.

(b): Chaiya Kongmanee, Ferdoushi Ahmed (2021). COVID-19 Impacts on Rubber Farmers in Thailand: A Study of Behavioral Change and Livelihoods. Universal Journal of Agricultural Research, 9(6), 277 - 288. DOI: 10.13189/ujar.2021.090606.
\end{abstract}

Copyright $\bigcirc 2021$ by authors, all rights reserved. Authors agree that this article remains permanently open access under the terms of the Creative Commons Attribution License 4.0 International License

\begin{abstract}
The impacts of COVID-19 have yet to manifest and are not predictable due to their scale or nature. This is shown in the infection, morbidity, and mortality rates, even more so in the implications on the agriculture sector and agricultural trade. On the other hand, it is well known that these effects will have an impact on both small-scale agriculture and other links in the production chain. This study aims to examine the current situations and problems of households socio-economic characteristics of Thai rubber farmers. The study correspondingly tries to identify the behavioral changes of rubber farmer households and livelihoods. The study found that many rubber farmers are going to be hooked on loan from the community source. However, on the contrary, a large number of people become able to adjust and balance their lives in line with their financial aspects. The study found that, $93.6 \%$ farmers had decreasing incomes, while $47.7 \%$ had adequacy of household incomes, and $38.5 \%$ had economic dependency, e.g., borrowing money from the system outside. In contrast, to highlight the positive effects on the economy, the study found that most of the farmers $(92.7 \%)$ saved money and considered more before spending during the pandemic. Similarly, an overwhelming portion $(86.2 \%)$ of the farmers applied the philosophy of sufficiency economy for livelihoods, while $74.3 \%$ had built institution and culture of saving for households, and $73.4 \%$ had attempted to seek more income to support their family.
\end{abstract}

Keywords COVID-19, Behavior Change, Livelihoods,
Rubber Farmer, Thailand

\section{Introduction}

A supply 'chain' is an integrated process wherein several various business entities work together to acquire raw materials which are then converted into final products and delivered to the customer [1]. The complexity of the supply chain may vary from industry to industry and from business to business. Thailand's rubber glove industry is aiming to expand its slice of the global market from $15 \%$ to $20 \%$ in the next five years. To meet that target, the Thai Rubber Glove Manufacturers Association (TRGMA) is pushing for increased investment and improved overall competitiveness in the industry. Association president Veerasith Sinchareonkul said the long-term aim was to grab a $40 \%$ share of the world market. The move follows a $20 \%$ jump in global demand for rubber gloves to 3.6 million amid the COVID-19 pandemic. Demand is expected to rise by another $10 \%$ next year [2]. Natural rubber productivity becomes one of the major drivers of incomes in the rural economy after intensively encouraging new areas of rubber plantation in 2011 that could imply that most farmers are inexperienced. Therefore, when farmers encounter a decline in production prices, it leads to adaptation in reducing household expenditures and production cost [3]. Rubber farmers have faced financial 
risks because of the plunge of natural rubber price, which made an extremely tough situation for most developing countries that possess non-contact farming and insufficient risk management practices and tools [4]. Natural rubber is used to manufacture more than fifty thousand types of products [5]. These range from footwear to conveyor belts to sophisticated products such as medical gloves and condoms. Most of the natural rubber is used in the automobile industry, particularly for tires. World rubber consumption per person, per year averages 10 to 15 kilograms [6]. This demonstrates its significance not only to the Thai economy but also to the development of the world industrial economy. As rubber demand continues to rise, Thailand's rubber plantation areas and manufacturers have grown significantly. However, instead of strengthening industry competitiveness, preliminary research has found that the industry has not gained a competitive advantage despite the high demand for rubber. This is due to high operating costs 2 and a lack of collaboration within the rubber supply chain [7, 8]. In order to gain a competitive advantage and to remain the leader in world rubber production, research is clearly needed to support decision making capabilities which will allow effective management and enhancement of the supply chain. Therefore, this study aims to examine the current situations and problems of farmer households' socio-economic characteristics in southern Thailand alongside attempts to identify the behavioral change of rubber farmer households as well as the effects of COVID-19 to livelihoods of rubber households in Thailand.

\section{Literature Review}

Due to the global pandemic caused by Covid-19, most of the countries in the ASEAN declared the agricultural sector essential to guarantee production security [9] and availability. However, the situation has implied several challenges related to the acquisition of inputs, hiring of labour, uncertainty on prices and demand, lack of liquidity and credit, and so on [10]. Along with other sectors, there is a big question ascending that what have been the immediate effects of the pandemic on rubber farming in the region and what should do to face challenges in this context.

The different pandemic diseases of viral origin that have befallen humanity shocked the economy, the environment, and any human work, such as livestock, agriculture, tourism, transport, education, health, fishing, mining, industry, commerce, etc. Currently, the human species face another pandemic, the epidemic of the new coronavirus (2019-nCoV) that generates the disease renamed COVID-19 [11]. This disease has caused great mortality in various countries of the world, causing governments to opt for social isolation, school closings, prohibition of public meetings and sports, restriction of public transport and border closures [12].

Applying trade restrictions, which are policies that could become a problem if barriers are maintained between countries that would trigger spikes in food prices and speculative behaviour in agricultural commodity markets of which the world's poor would be the most affected [10]. Trade channels must remain open so that international markets can play a critical role in avoiding food shortages by mitigating the inevitable global economic downturn. Attention must also be paid to measures that will help prevent a global recession and minimize further increases in food insecurity, thus governments will need to provide fiscal stimulus, including resources to contain the spread of the disease [13]. Ivanov [14] in his research found that COVID-19 is shown to represent a specific case of supply chain disruption on a long-term and unpredictable scale in addition to the simultaneous propagation of disruptions and unknowns that make it difficult to fully determine the impact of epidemic outbreaks on the supply chain and appropriate measures of reaction to these.

A new understanding of supply chain risk management and resilience is provided by positioning outbreaks as a specific type of supply chain risk and offering an approach that supports decision makers during the epidemic outbreaks [14]. The pandemic gives innovation as an excuse, for example China invests in agricultural technology to reduce human contact in these tasks. In Africa, mobile telephony is innovating access to markets, prices and weather data, as well as facilitating money transfers. Peru is assessing the benefits of innovative legislation to formalize agricultural labor and has linked it directly to the seasonality of crops [15]. With the pandemic, the most affected sectors have been tourism, hotels, commerce, among others, causing great losses worldwide and in the same way, agricultural activities were affected, including small and medium-sized companies in this area, and it depends on governments' policies to respond to these impacts [16]. In the same way, the closure of businesses and the discontinuity of supplies, raised an alarm about food and food security among the authorities, who began to formulate policies to mitigate these problems early [12]. On the other hand, in some countries there is a great demand for food, reflected by the needs of the population, which, combined with limited supplies, due to interruptions in agricultural production chains, could generate an unprecedented crisis [17]. In other words, we are in a historical moment that marks humanity and directly affects agriculture and agribusiness, specifically the production chain and its related links [18].

The importance of food safety is widely known, but in these times, it is necessary to ensure that it is met at all levels. First, because consumers have the right to access food to improve their immune system through the adoption of healthier diets, the availability of bioactive ingredients in food and functional foods, but their availability could 
become critical, due to the growth in demand, of these products. Second, food safety is an important issue to prevent the spread of COVID-19 among producers, retailers, and consumers. Finally, food insecurity problems have arisen, due to social isolation Galanakis [19], which was reflected in the change in eating habits, through the intake of ready-to-eat or easily prepared foods, which do not have the necessary nutritional intake for a good diet.

The impacts of COVID-19 have yet to manifest and are not predictable due to their scale or nature. This is shown in the infection, morbidity and mortality rates, even more so in the implications on the agriculture sector and agricultural trade. On the other hand, it is well known that these effects will have an impact on both small-scale agriculture and other links in the production chain [20]. The promoters of agriculture, their workers, make up an area of particular complexity to carry out development, implementation and supervision activities, to contain and temporarily mitigate the effects of the pandemic [21]. Once the restriction and immobility measures were established, the acquisition of food considered non-essential was made difficult, but the supply of agricultural products produced locally was continued, in order to guarantee the availability of food for consumers. Similarly, due to these restrictions, restaurants and hotels closed, and farmers were affected by the reduction in demand for their products, as well as their deterioration due to their perishability [22].

Our eating habits generate an impact, and therefore agriculture under the focus of increasing its production, yield and income, considers it necessary to take an advantage of the environment to achieve this, being key to face this pandemic. The presence of COVID-19 shows that planning and building a comprehensive and sustainable system over time, guarded by an adequate and responsible paradigm with the environment and society are necessary to ensure the population's nutrition [23]. The commercial seed houses as well as fertilizers and pesticides must continue with this activity above the basic demand line. The purchase and delivery of agricultural inputs should be promoted by agricultural cooperatives, industrial associations and the government because they are necessary to guarantee the free production of food [24]. It is notable that the availability of foods and products from agriculture as well as the agricultural inputs necessary for its production were impacted by the immobilization measures in the small agricultural producer economy [25]. In the same way, in the areas where transportation is normalized, the price of necessity products rose accompanied by [26]. The broad objective of this work is to analyze the current situation of rubber farmers and livelihoods of rubber households in regard to COVID-19 pandemic.

\section{Materials and Methods}

The study employed both primary and secondary data to fulfill the objectives. Secondary data were documents and reviewing data in the form of statistical reports, research reports, papers, information, and official documents, including the prospective documents by international organizations. Primary data belonged to short field survey and in-depth interview to collect data the selected samples with structured-questionnaires and semistructured-questionnaires. Population involved in this study were farmers who are related to the primary supply chain of rubber business systems in Songkhla province. Descriptive statistics, parametric statistics and prospective analysis have been applied to analyse the impact of COVID-19 to the rubber business system and supply chain. The descriptive statistics is an analysis of data by using simple statistics such as frequency, distribution, percentage, and mean to present the analysed data in the format of tables related to the issues before and after the pandemic.

\section{Results and Discussions}

\subsection{Current Situations: Socio-Economic Characteristics and Production Management}

From demographic data for social characteristics of rubber farmer households (Table 1), the study found that the heads of families were males for $63.3 \%$ with the proportion higher than those of females for only $36.7 \%$. For the age of heads of families of rubber farmers, the study indicated that the average age was 52.80 years which farmers for $62.6 \%$ had ages at $41-60$ years old with the lower ages at $23.8 \%$ being $>60$ years old and $13.6 \%$ being at 21-40 years old. For the religious profession of the heads of families of rubber farmers, the study found that $99.1 \%$ or 108 farmers were Buddhists and $0.9 \%$ were Muslims or 1 farmer. For agricultural career, labor type, and household-labor type, the study found that $100 \%$ or 109 farmers had the agricultural career of working with rubber plantations, $27.5 \%$ or 39 farmers worked with orchard, $13.8 \%$ or 15 farmers raised animals, $3.7 \%$ or 4 farmers worked with oil palm plantations, and $1.8 \%$ or 2 farmers did rice farming. For labor type, the study found that $85.3 \%$ or 93 farmers used household labor, $11.9 \%$ or 13 farmers used hired tapping labor, $1.9 \%$ or 2 farmers used permanent labor, and $0.9 \%$ or 1 farmer used temporary labor. For household-labor type, the study found that $94.5 \%$ or 103 farmers worked in their lands and $5.5 \%$ or 6 farmers were hired for tapping rubber (tapping rubber in other plots of different owners). 
Table 1. Demographic Data for Economic Characteristics of Rubber Farmers

\begin{tabular}{|c|c|c|}
\hline Item & Number $(n=109)$ & Percentage \\
\hline \multicolumn{3}{|l|}{ Total household landholding } \\
\hline$\leq 20$ & 63 & 57.8 \\
\hline $21-50$ & 33 & 30.3 \\
\hline \multirow{2}{*}{$\begin{array}{c}>51 \\
\text { Average }\end{array}$} & 13 & 11.9 \\
\hline & \multicolumn{2}{|c|}{27.61} \\
\hline \multicolumn{3}{|l|}{ Rubber plantation holding } \\
\hline plot 1 & 72 & 66.1 \\
\hline plot 2 & 25 & 22.9 \\
\hline \multirow{2}{*}{$\begin{array}{c}\text { plot } 3 \\
\text { Average }\end{array}$} & 12 & 11.0 \\
\hline & \multicolumn{2}{|c|}{25.21} \\
\hline \multicolumn{3}{|l|}{ Household net income } \\
\hline$\leq 10,000$ & 22 & 20.2 \\
\hline $10,001-60,000$ & 33 & 30.3 \\
\hline$>60,000$ & 54 & 49.5 \\
\hline Average & \multicolumn{2}{|c|}{90571.27} \\
\hline \multicolumn{3}{|l|}{ Incomes from agricultural sector } \\
\hline$\leq 150,000$ & 25 & 22.9 \\
\hline $150,001-300,000$ & 50 & 45.9 \\
\hline$>300,001$ & 34 & 31.2 \\
\hline Average & \multicolumn{2}{|c|}{273665.94} \\
\hline \multicolumn{3}{|l|}{ Incomes from rubber plantations } \\
\hline$\leq 150,000$ & 28 & 25.9 \\
\hline $150,001-300,000$ & 47 & 43.5 \\
\hline$>300,001$ & 34 & 30.6 \\
\hline Average & \multicolumn{2}{|c|}{265523.04} \\
\hline Average & \multicolumn{2}{|c|}{12905.33} \\
\hline \multicolumn{3}{|l|}{ Pension/old age allowance } \\
\hline$\leq 100,000$ & 17 & 73.6 \\
\hline \multirow{2}{*}{$\begin{array}{c}\leq 100,000 \\
100,001-600,000 \\
\text { Average }\end{array}$} & 6 & 26.5 \\
\hline & \multicolumn{2}{|c|}{79721.74} \\
\hline
\end{tabular}

From the demographic data for social characteristics of rubber farmer households (Table 1), the study found that the total land holding of households for an average at 27.6 rai, 63 farmers for $57.8 \%$ owned lands not $>20$ rai, 33 farmers for $30.3 \%$ owned lands for $21-50$ rai, and 13 farmers for $11.9 \%$ owned lands $>51$ rai. For rubber plantation holding, the study revealed that the farmers held, on average, 25.21 rai of land where $66.1 \%$ of the farmers owned plot 1, 22.9\% owned plot 2, and $11 \%$ owned plot 3 .

For incomes of farmer households, the study found that farmer households had an average net income at 90571.27 baht/year, 54 farmers for $49.5 \%$ having net income > $60,001 \mathrm{baht} / \mathrm{year}, 33$ farmers for $30.3 \%$ having net income
$10,001-60,000$ baht/year, and 22 farmers for $20.2 \%$ having net income $<10,000$ baht/year. For incomes from the agricultural sector, the study found that farmers had incomes from the agricultural sector at an average of $273665.94 \mathrm{baht} / \mathrm{year}, 50$ farmers for $45.9 \%$ having those for 105,001-300,000 baht/year, 34 farmers for $31.2 \%$ having those $>300,001 \mathrm{baht} / \mathrm{year}, 25$ farmers for $22.9 \%$ having those $<105,000 \mathrm{baht} / \mathrm{year}$. For incomes from the rubber plantation, the study found that farmers had incomes from the rubber plantation for an average at $265523.04 \mathrm{baht} / \mathrm{year}, 47$ farmers for $43.5 \%$ having those for 150,001-300,000 baht/year, 34 farmers for 30.6\% having those > 300,001 baht/year, and 28 farmers for $25.9 \%$ having those $<150,000$ baht/year. 
Table 2. Production, Management, and Production Technology of Farmer Households

\begin{tabular}{|c|c|c|}
\hline Item & Number $(n=109)$ & Percentage \\
\hline Recent age of rubber tree & & \\
\hline $2-20$ & 84 & 77.1 \\
\hline $21-40$ & 25 & 22.9 \\
\hline Average & \multicolumn{2}{|c|}{17.81} \\
\hline \multicolumn{3}{|l|}{$\begin{array}{c}\text { Fertilizer application } \\
\text { (specify: type of fertilizer/ frequency of application / } \\
\text { price/expense for fertilizer application) } \\
\text { Type of fertilizer }\end{array}$} \\
\hline Chemical fertilizer & & 53.2 \\
\hline Organic \& chemical fertilizer & & 28.5 \\
\hline Mixed fertilizer & & 5.5 \\
\hline Organic fertilizer & & 9.2 \\
\hline No fertilizer & & 3.7 \\
\hline \multicolumn{3}{|l|}{ Frequency of application } \\
\hline 1 & 77 & 73.3 \\
\hline 2 & 26 & 24.8 \\
\hline 3 & 2 & 1.9 \\
\hline Price & $\mathrm{N}=105$ & \\
\hline$\leq 10,000$ & 32 & 30.5 \\
\hline $10,001-70,000$ & 57 & 54.3 \\
\hline$>70,000$ & 16 & 15.2 \\
\hline Average & \multicolumn{2}{|c|}{33254.86} \\
\hline Expense & \multicolumn{2}{|l|}{$\mathrm{N}=57$} \\
\hline$\leq 3,000$ & 27 & 47.4 \\
\hline $3,001-7,000$ & 21 & 36.8 \\
\hline$>7,001$ & 9 & 15.8 \\
\hline Average & \multicolumn{2}{|c|}{5374.04} \\
\hline \multicolumn{3}{|l|}{ Type of tapping labor } \\
\hline family labor & 91 & 83.5 \\
\hline hired labor & 18 & 16.5 \\
\hline \multicolumn{3}{|l|}{ Number of labor (people) } \\
\hline 1 & 40 & 36.7 \\
\hline 2 & 47 & 43.1 \\
\hline 3 & 9 & 8.3 \\
\hline 4 & 4 & 3.7 \\
\hline 5 & 8 & 7.3 \\
\hline 6 & 1 & 0.9 \\
\hline \multicolumn{3}{|l|}{ tapping hired contract $* *$} \\
\hline $20: 80$ & 1 & 0.9 \\
\hline $45: 55$ & 3 & 2.7 \\
\hline $50: 50$ & 14 & 12.8 \\
\hline $60: 40$ & 3 & 2.8 \\
\hline $\begin{array}{l}\text { Types of rubber products for selling } \\
\text { latex }\end{array}$ & 109 & 100 \\
\hline
\end{tabular}

For production and management of recent farmer households (Table 2), the study found that average age of recent rubber trees was at 17.81 years old, while 84 farmers for $77.1 \%$ owned rubber trees at ages 2-20 years old and 25 farmers for $22.9 \%$ owned rubber trees at ages 21-40 years old.

For fertilizer application, the study found that 58 farmers for $53.2 \%$ applied chemical fertilizer, 31 farmers for $28.5 \%$ applied organic and chemical fertilizers, 10 farmers for $9.2 \%$ applied organic fertilizer, 6 farmers for $5.5 \%$ applied mixed fertilizer, and 4 farmers for $3.7 \%$ did not apply any fertilizer. For the frequency of fertilizer application, the study found that 77 farmers for $73.3 \%$ applied fertilizer 1 time/year, while 26 farmers for $24.8 \%$ 
applied fertilizer 2 times/year, and 2 farmers for $1.9 \%$ applied fertilizer 3 times/year. For price/expense for fertilizer application, the study found that farmers paid for an average expense for fertilizer application at $33,254.86$ baht/year, 57 farmers for $54.3 \%$ paying for 10,001-70,000 baht/year, 32 farmers for 30.5\% paying < 10,000 baht/year, and 16 farmers for $15.2 \%$ paying > 70,001 baht/year.

For tapping hired contract, the study found that 14 farmers for $12.8 \%$ used the proportion of 50:50, 3 farmers for $2.8 \%$ using the proportion of $60: 40,3$ farmers for $2.7 \%$ using the proportion of $45: 55$, and 1 farmer for $0.9 \%$ using the proportion of 20:80. For types of rubber products for selling, the study found that 109 farmers for $100 \%$ sold fresh latex.

\subsection{Effects of COVID-19 to Society, Economy, and Livelihood of Rubber Households}

The Effects of COVID-19 to society of rubber households could be divided into negative effects and positive effects. For the negative effects of COVID-19 on society of rubber households, the study indicated the following issues.

\subsubsection{Effects on Society}

For negative effects on society of receiving welfare/social policy (Figure 1), the study found that receiving supports for the cost of utility bill gave the most effect at 67\%, 5,000 baht-relief measures at 58.7\%, 3 -month free internet and extending tax payment had the same effect proportions at $35.8 \%$, and lower water bill measure had the least effects at $30.3 \%$.

For the negative effects on society of having interaction in the community during COVID-19 (Figure 2), the study found that having social distancing was the most effective at $89 \%$, having more meetings online at $72.5 \%$, having less interaction among people in the community at $71.6 \%$, and closing community or having community closed for preventing COVID-19 disease at 50.5\%.

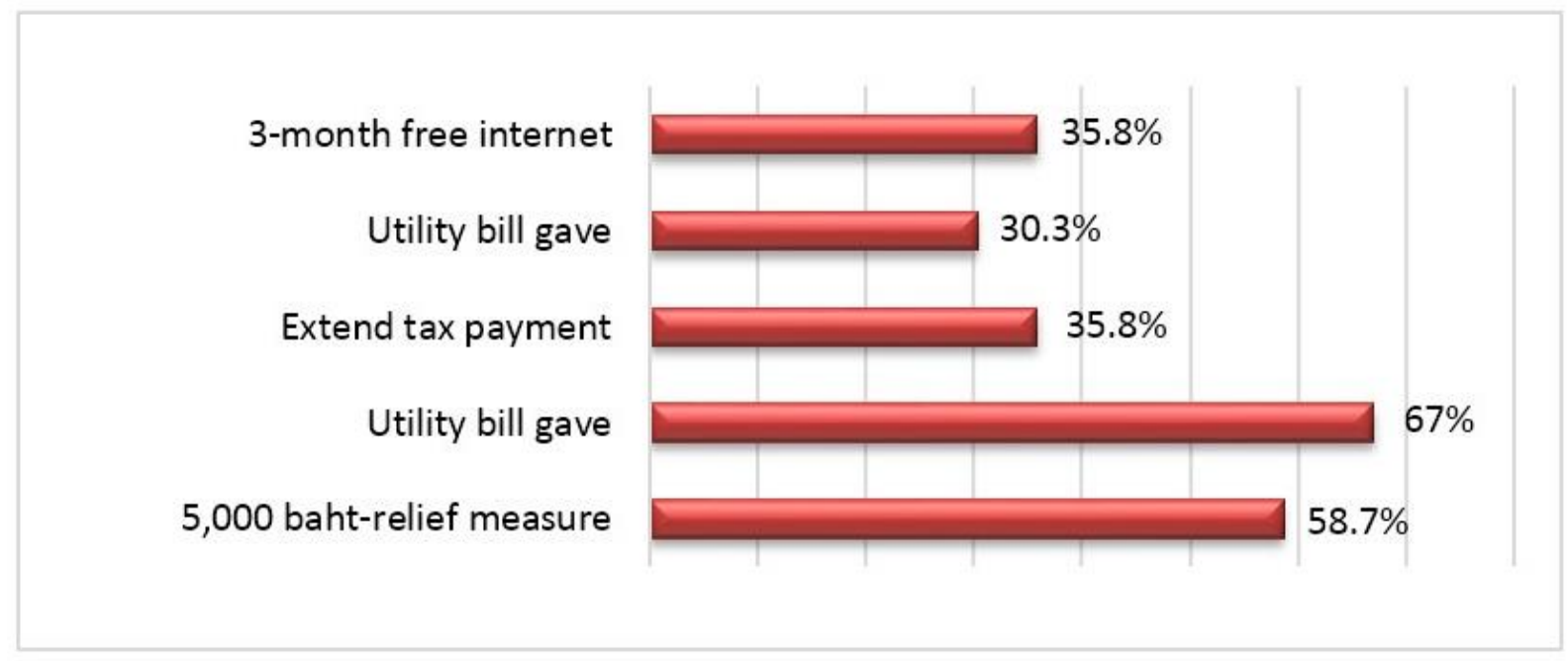

Figure 1. Effects to Society of Receiving Welfare/Social Policy Rubber Households

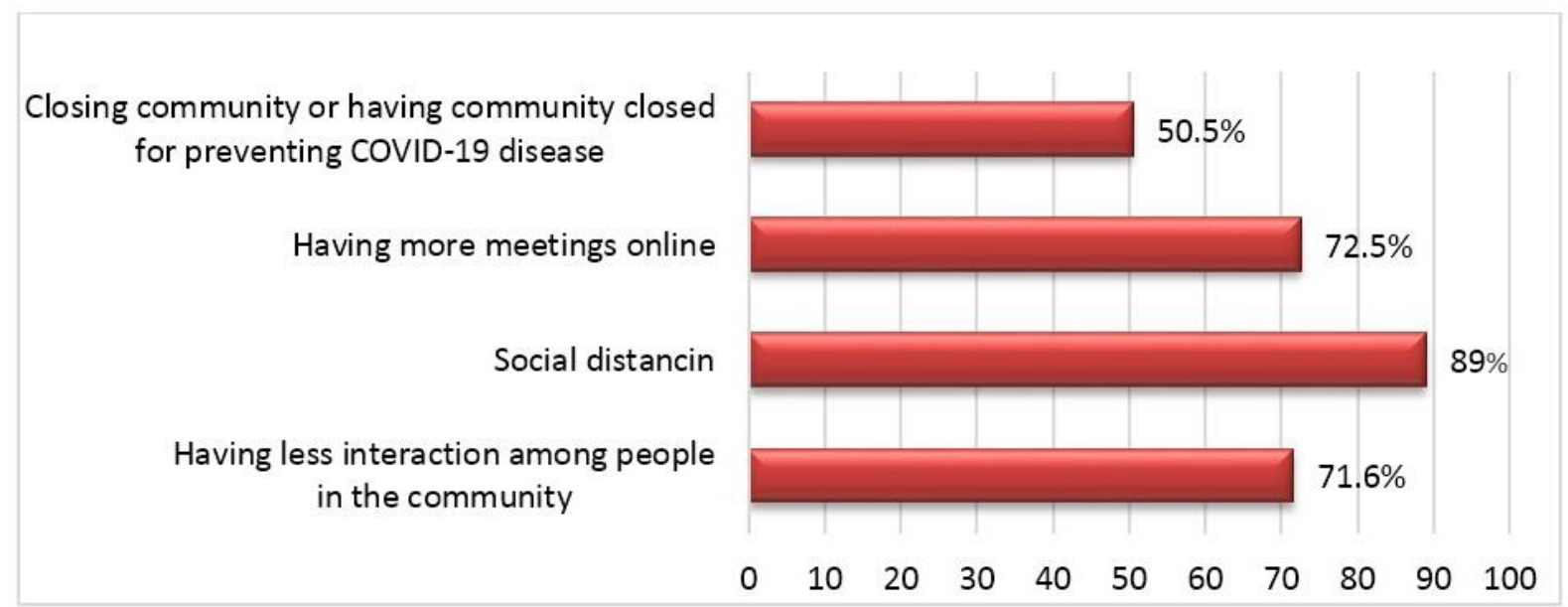

Figure 2. Effects to Society of Having Interaction in the Community during COVID-19 


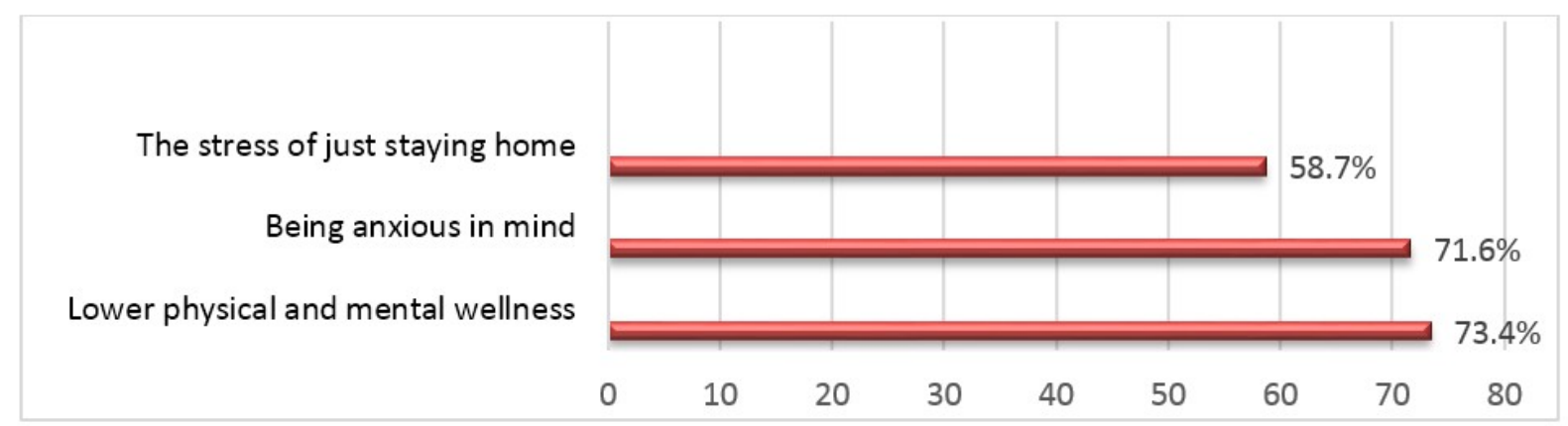

Figure 3. Negative Effects to Society of Having Wellness of Rubber Farmers

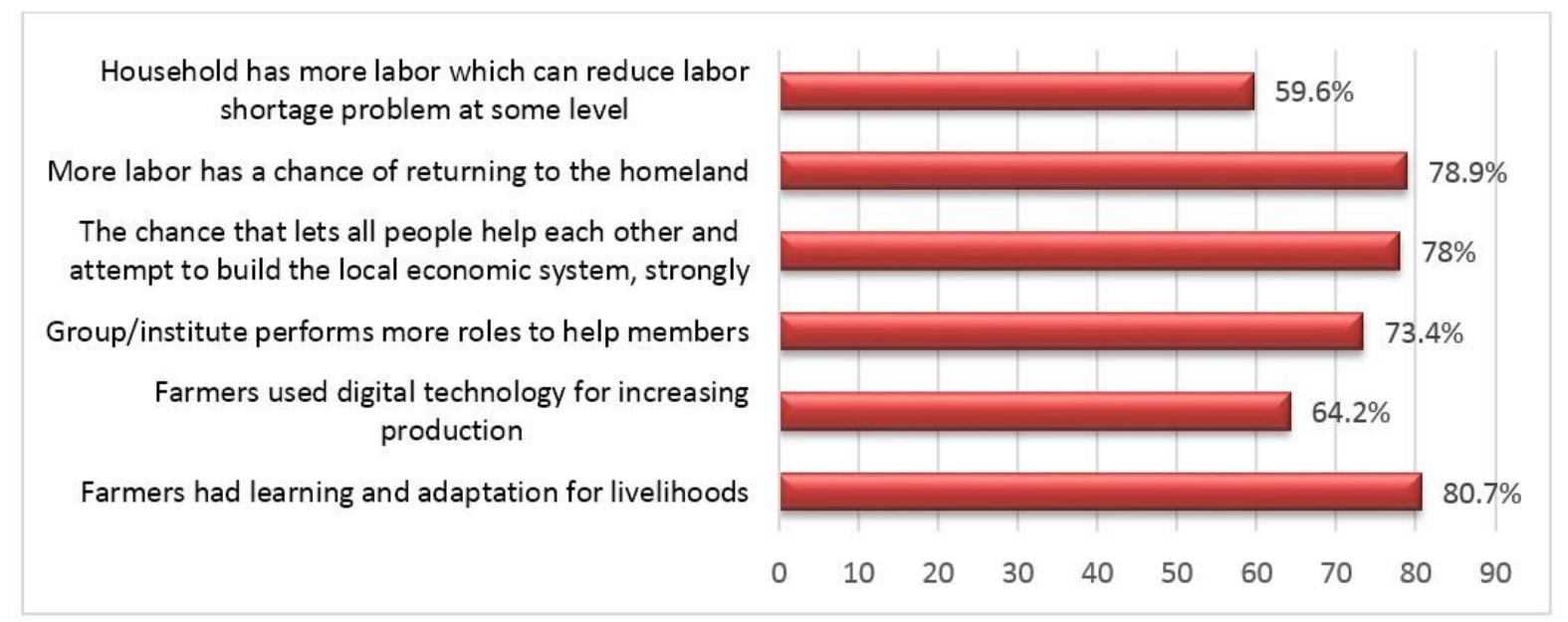

Figure 4. Positive Effects to Learning Society and Adaptation

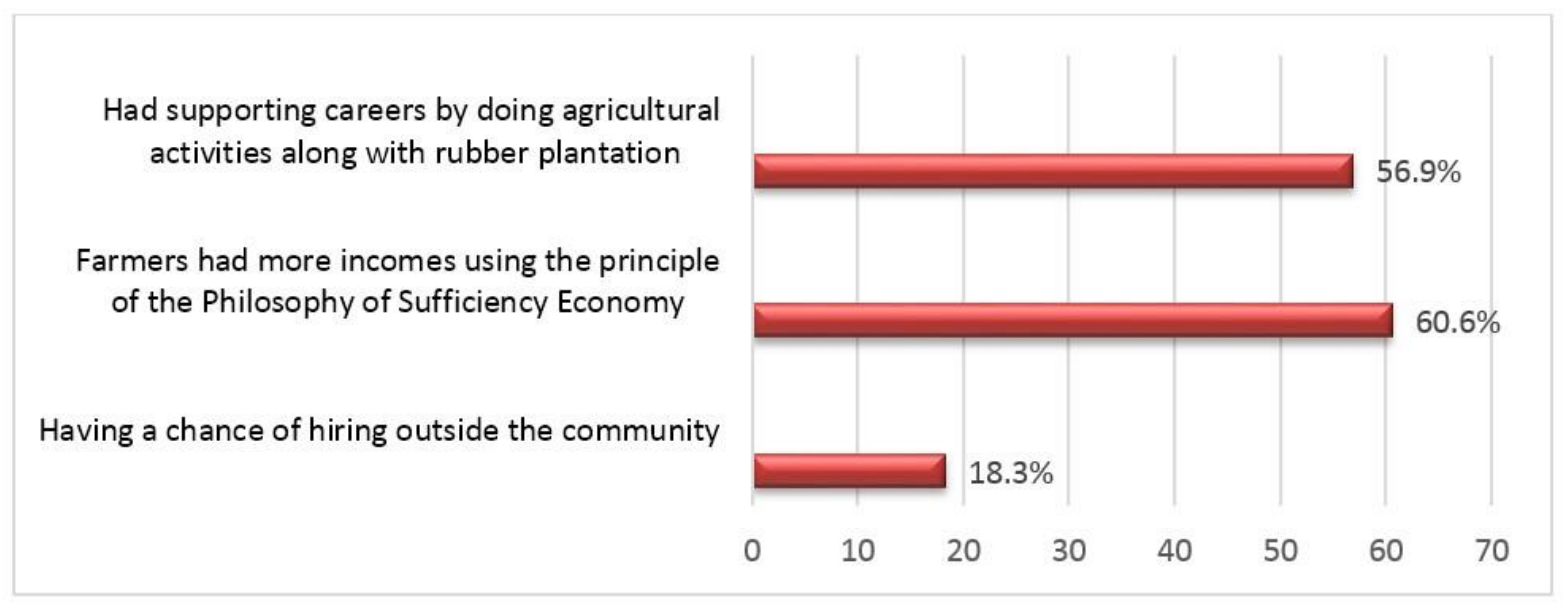

Figure 5. Positive Effects to Society of Supporting Careers for More Incomes

For negative effects on society of having wellness of rubber farmers (Figure 3), the study found that farmers had lower physical and mental wellness at $73.4 \%$ behind being anxious in mind at $71.6 \%$, and had the least of the stress of just staying home at $58.7 \%$

Regarding positive effects of COVID-19 on society of rubber households, the study indicated the above issues (figure 4).
For the positive effects on learning society and adaptation (Figure.4), the study found that farmers had learning and adaptation for livelihoods at $80.7 \%$, more labor has a chance of returning to the homeland at $78.9 \%$, the chance that lets all people help each other and attempt to build the local economic system, strongly at $78 \%$, group/institute performs more roles to help members at $73.4 \%$, farmers used digital technology for increasing 
production, creating more values, and approaching the market for agricultural products at $64.2 \%$, and household has more labor which can reduce labor shortage problem at some levels at the least for $59.6 \%$.

For positive effects on society of supporting careers for more incomes (Figure 5), the study found that farmers had more incomes using the principle of the Philosophy of Sufficiency Economy at the most for $60.6 \%$, had supporting careers by doing agricultural activities along with rubber plantation at $56.9 \%$, and having a chance of hiring outside the community at the least for $18.3 \%$.

For effects to society of getting together for cultural activities in the community (Figure 6), the study found that farmers involved in the religious activity such as going to the temple for doing merit were at the most for $63.3 \%$, prepared aid packages for poor people in the community at $41.3 \%$ and did the activity of community little free pantry at the least for $30.3 \%$.

\subsubsection{Effects on Economy}

The Effects of COVID-19 on the economy of farmer households could be divided into negative effects and positive effects.

For Negative Effects on Economy of Problems of Household Economic Status (Figure 7), the study found that farmers had adequacy of financial assets at $74.3 \%$, transportation systems, and logistic limitation were disrupted due to measures to restrain pandemic with more creating of debts for more expenses at 59.6\%, had more unemployment in households and community at 58.3\%, had more crimes in area/community, and had sold of mortgaging assets at the least effect for $45.9 \%$.

For negative effects on the economy of consuming behavior of rubber farmer households (Figure 8), the study found that farmers had fewer consuming products bought from the community market and changed to buy more products from supermarkets at $69.7 \%$ and products from online at 55\%.

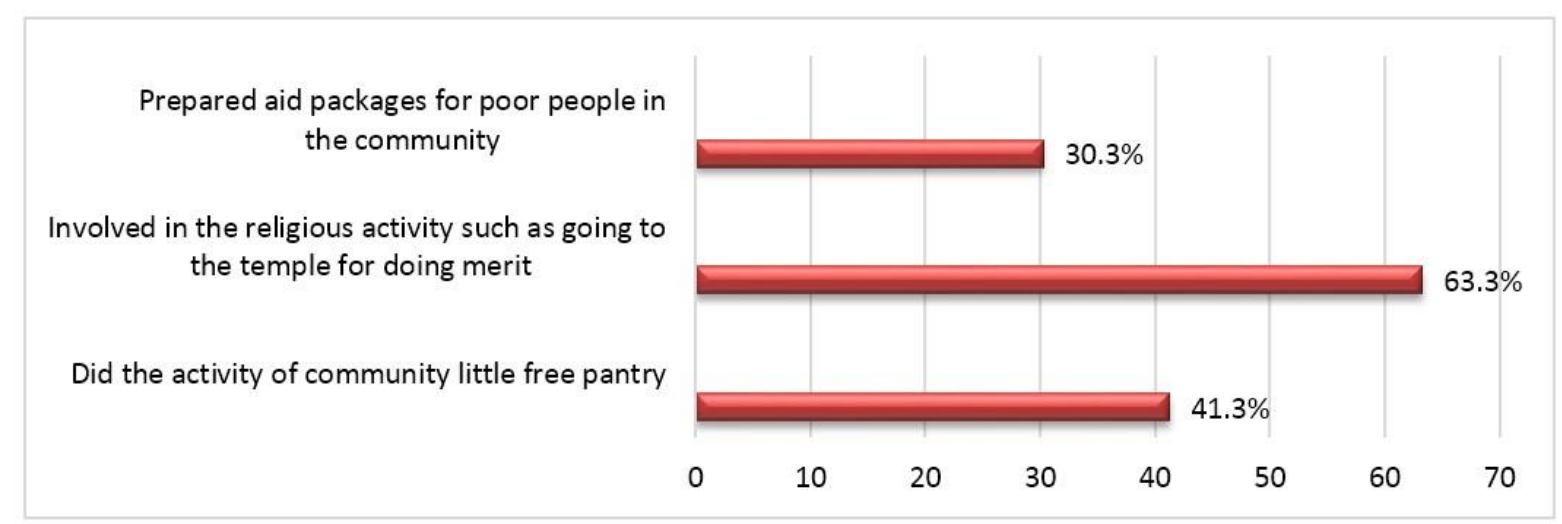

Figure 6. Effects to Society of Getting Together for Cultural Activities in the Community

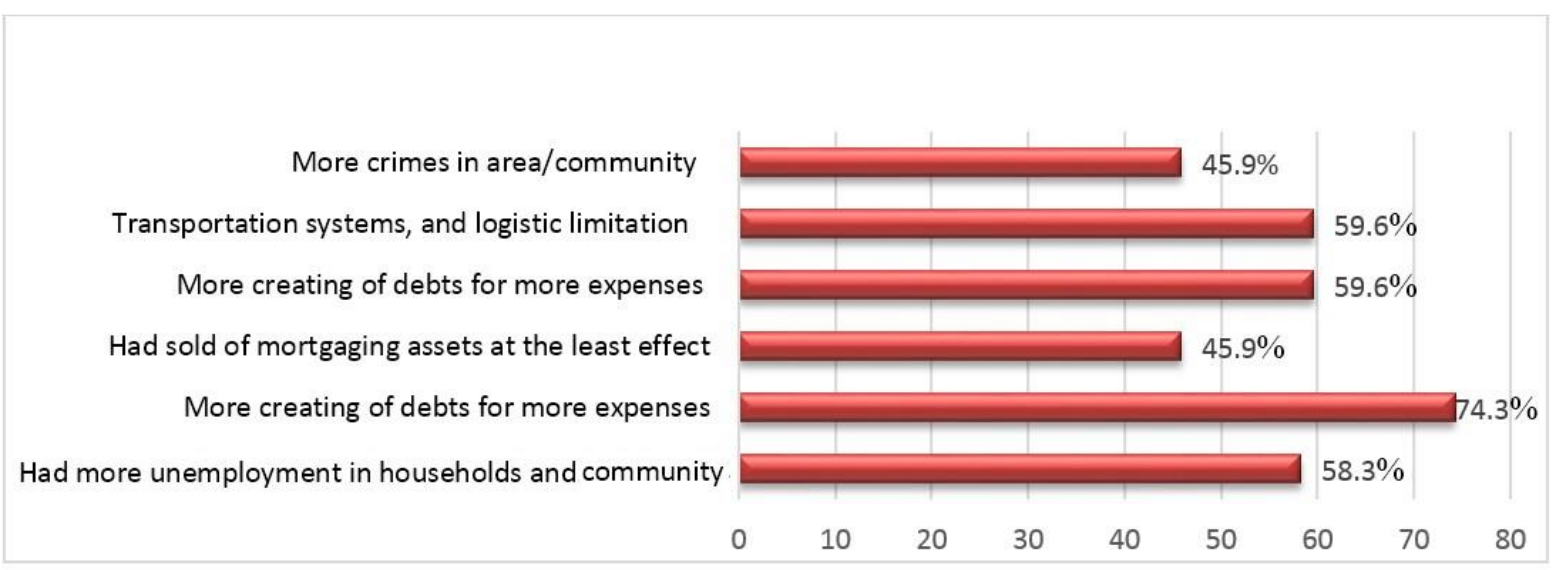

Figure 7. Negative Effects to Economy of Problems of Household Economic Status 


\section{Sold products from online}

Farmers had less consuming products bought from the community market and changed to buy more products from supermarkets

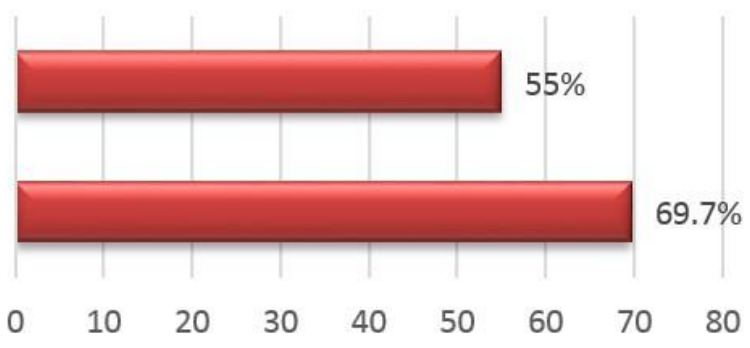

Figure 8. Negative Effects to Economy of Consuming Behavior of Rubber Farmer Households

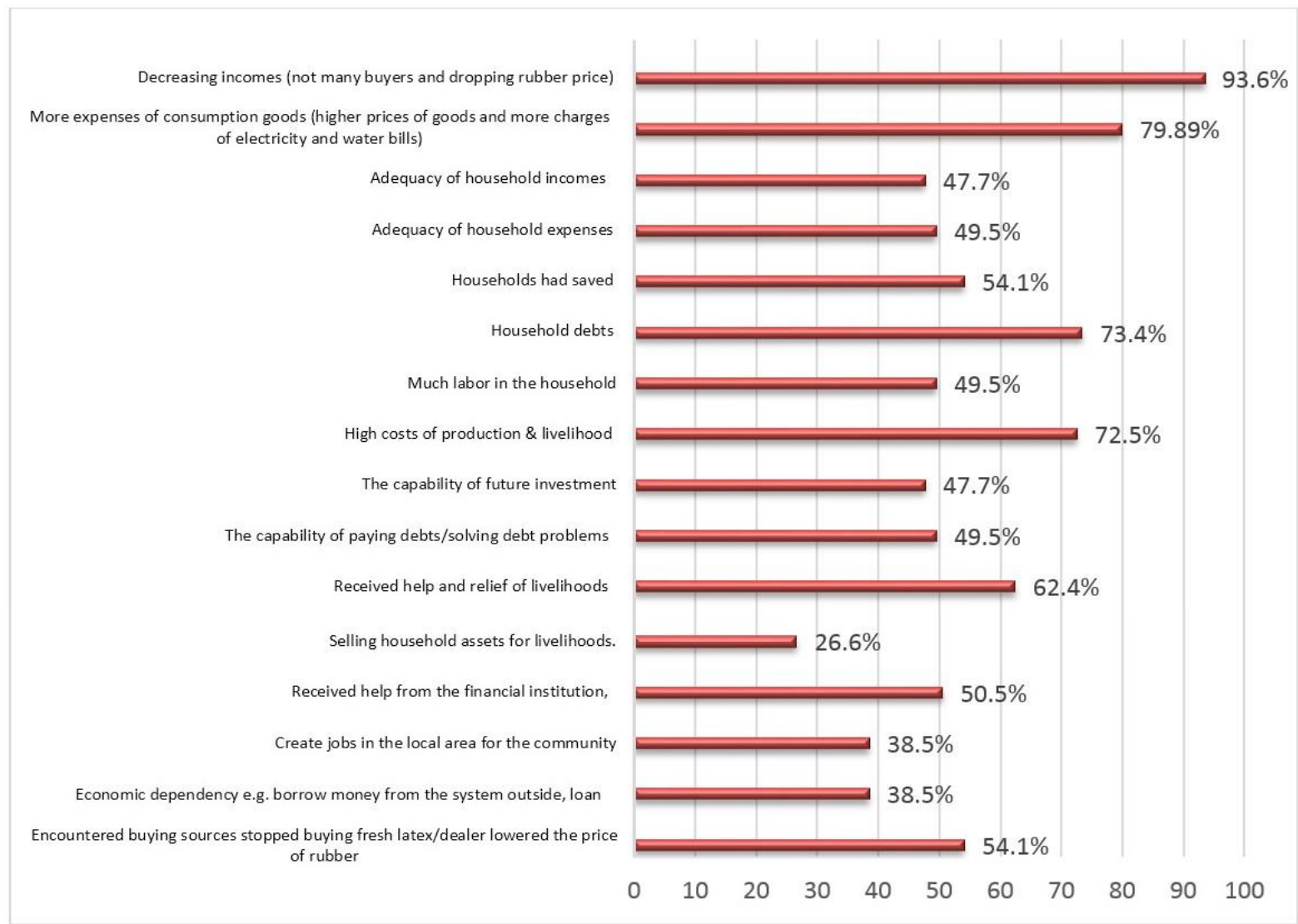

Figure 9. Negative Effects of Rubber Farmer Household Income and Expense

building institution and culture of saving for households

Social insurance system for rubber farmer households

Build strong local economic system from the inside

Attempting to seek more incomes by supporting

Used Philosophy of Sufficiency Economy for livelihoods

Save and considering more before spending

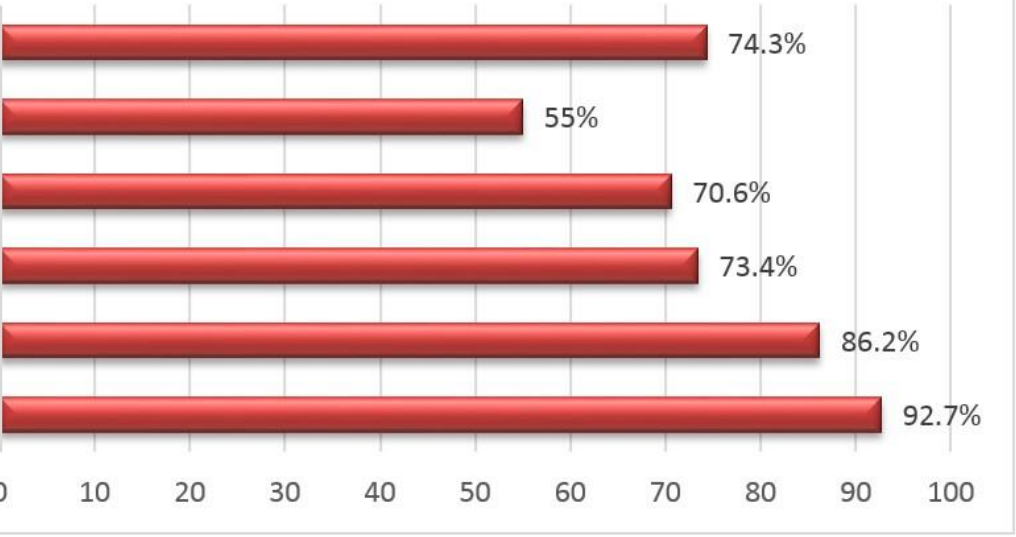

Figure 10. Positive Effects to Economy of Rubber Farmer Households 
While the negative effects of COVID-19 on rubber farmer households' income and expense were taken into consideration (Figure 9), the study found that most of farmers $(93.6 \%)$ had experience of decreasing incomes (due to not many buyers and dropping rubber price), while an overwhelming portion of farmers $(79.8 \%)$ had to spend more on consumption goods (because of higher prices of goods and more charges of electricity and water bills). Similarly, a significant portion $(73.4 \%)$ of the farmers fell in the trap of household debts and $72.5 \%$ of the farmers experienced of high costs of production and livelihood while $62.4 \%$ had received help and relief of livelihoods. The study also revealed that more than half $(54.1 \%)$ of the farmers encountered problem with buying sources as the dealers stopped buying fresh latex and consequently lowered the price of rubber. Nearly half of the respondents $(49.5 \%)$ had adequacy of household expenses (due to much labor in the household) while the same proportion (49.5\%) of the farmers had the capability of paying debts/solving debt problems. $47.7 \%$ had adequacy of household incomes and the capability of future investment at the same proportion, $38.5 \%$ having to create jobs in the local area for the community and economic dependency e.g., borrow money from the system outside, loan at the same proportion, and $26.6 \%$ having sold household assets for livelihoods.

For positive effects on the economy (Figure 10), the study found that farmers for $92.7 \%$ had to save and consider more before spending. $86.2 \%$ used Philosophy of Sufficiency Economy for livelihoods, $74.3 \%$ had building institution and culture of saving for households, $73.4 \%$ attempting to seek more incomes by supporting, $70.6 \%$ having to build strong local economic system from the inside, and 5\% had.

\subsubsection{Effects on households}

For effects on livelihoods of rubber farmer households in terms of issues related to capital change for livelihoods of rubber farmer households, the study indicated the following details (Table 3).
Table 3. Capital Change for Livelihoods

\begin{tabular}{|c|c|c|c|}
\hline & & & \\
\hline Capitals & Units & Res & \\
\hline Human capital & $\%$ & $\begin{array}{c}\text { Had effects } \\
\text { No effect }\end{array}$ & $\begin{array}{l}(89.9) \\
(10.1)\end{array}$ \\
\hline Natural capital & $\%$ & $\begin{array}{l}\text { Had effects } \\
\text { No effect }\end{array}$ & $\begin{array}{l}(83.5) \\
(16.5)\end{array}$ \\
\hline Financial capital & $\%$ & $\begin{array}{l}\text { Had effects } \\
\text { No effect }\end{array}$ & $\begin{array}{c}(92.7) \\
(7.3)\end{array}$ \\
\hline Physical capital & $\%$ & $\begin{array}{l}\text { Had effects } \\
\text { No effect }\end{array}$ & $\begin{array}{l}(89.0) \\
(11.0)\end{array}$ \\
\hline Social capital & $\%$ & $\begin{array}{l}\text { Had effects } \\
\text { No effect }\end{array}$ & $\begin{array}{c}(95.4) \\
(4.6)\end{array}$ \\
\hline
\end{tabular}

\subsection{Livelihood Results of Socioeconomic Issues Compared with Pre-COVID-19 Situation}

The effects of COVID-19 on the farmers livelihood have been compared with the before COVID-19 situation (Table 4). The study found that the farmers' total household income during the COVID-19 was little higher (average level at 4.08) than that of before COVID-19. Similarly, the farmers ability to pay for the household debt during the COVID-19 was little higher (average level at 3.73) than that of pre COVID-19. On the other hand, the farmers maintained a higher level of relationship (average level at 3.65) among household members during the COVID-19 pandemic. Similarly, the farmers were able to maintain a higher level of relationship (average level at 3.59) among brothers, sisters, and relatives while a medium level of relationship (average level at 3.47) were maintained with neighbors and people in the community. The study also found that the level of the farmers household saving during COVID-19 was adequately higher (average level at 3.61) than that of before COVID-19. On the other hand, the level of household debt during COVID-19 was more or less same (average level at 2.76) as before COVID-19. The "health conditions" of the household members during the pandemic was better (with a medium average level at 3.17) as compared to before pandemic. The farmers were also able to maintain a higher level (average level at 2.94) of social networks (participated in the group/cooperative and knew more people) during the COVID-19 than that of pre COVID-19 situation. 
Table 4. Effects of COVID-19 to Livelihood Compared with Those before COVID-19 ( $\mathrm{N}=109)$

\begin{tabular}{|c|c|c|}
\hline Items & Average & Level \\
\hline $\begin{array}{l}\text { 1. Level of having total current household income compared with household income } \\
\text { before COVID-19 }\end{array}$ & 4.08 & High adequacy \\
\hline $\begin{array}{l}\text { 2. Level of having current household debt compared with household debt before } \\
\text { COVID-19 }\end{array}$ & 2.76 & Medium adequacy \\
\hline $\begin{array}{l}\text { 3. Level of having current household saving compared with household saving before } \\
\text { COVID-19 }\end{array}$ & 3.61 & High adequacy \\
\hline $\begin{array}{l}\text { 4. Level of being able to pay for the household debt compared with household income } \\
\text { before COVID-19 }\end{array}$ & 3.73 & High adequacy \\
\hline $\begin{array}{l}\text { 5. Level of having household for being able to currently compared with household } \\
\text { income before COVID- } 19\end{array}$ & 3.61 & High adequacy \\
\hline $\begin{array}{l}\text { 6. Level of having "health conditions" of household members compared with that } \\
\text { before COVID-19 }\end{array}$ & 3.17 & High adequacy \\
\hline $\begin{array}{l}\text { 7. Level of having relationship among household members compared with that before } \\
\text { COVID-19 }\end{array}$ & 3.65 & High adequacy \\
\hline $\begin{array}{l}\text { 8. Level of having relationship among brothers, sisters, and relatives compared with } \\
\text { that before COVID-19 }\end{array}$ & 3.59 & High adequacy \\
\hline $\begin{array}{l}\text { 9. Level of having relationship among neighbors and people in the community } \\
\text { compared with that before COVID- } 19\end{array}$ & 3.47 & High adequacy \\
\hline $\begin{array}{l}\text { 10. Level of having social networks (participated in the group/cooperative and knew } \\
\text { more people) compared with that before COVID-19 }\end{array}$ & 2.94 & Medium adequacy \\
\hline $\begin{array}{l}\text { 11. Level of having total household image of livelihood compared with that before } \\
\text { COVID-19 }\end{array}$ & 3.43 & High adequacy \\
\hline Average & 3.45 & High adequacy \\
\hline
\end{tabular}

*Notes: 4.21-5.00 highest adequacy, 3.41-4.20 high adequacy, 2.61-3.40 medium adequacy, 1.81-2.60 low adequacy, and least adequacy 1.00-1.80

Table 5. Structure and Policy Changes

\begin{tabular}{|l|c|l|}
\hline \multicolumn{1}{|c|}{ Issues } & Units & \multicolumn{1}{|c|}{ Results } \\
\hline $\begin{array}{l}\text { 1. Participating in activities and received help from } \\
\text { working units/government sectors }\end{array}$ & $\%$ & Receive (56.0) No receive (44.0) \\
\hline 2. Having help from the following working units & $\%$ & $\begin{array}{l}\text { the project of no one was left behind (54.1), the project of farmers } \\
\text { remedy (0.9), and union cooperative limited (0.9) }\end{array}$ \\
\hline 3. Receiving help for livelihoods & $\%$ & $\begin{array}{l}\text { had better living (82.0), had worse living (8.2), and did not affect } \\
\text { living (9.8) }\end{array}$ \\
\hline
\end{tabular}

Effects on livelihoods of rubber farmer households in terms of structure and policy changes have been presented in Table 5. It can be seen that farmers for $56.0 \%$ had to participate in activities/projects and/or received bits of help from working units/government sectors and $44.0 \%$ had no participation. Having help from working units, farmers for $54.1 \%$ involved the project of no one was left behind, $0.9 \%$ involved the project of farmers remedy, and $0.9 \%$ involved union cooperative limited. It was found that a overwhelming portion $(82.0 \%)$ of the farmers had better living after receiving help for livelihoods while a significantly lower portion $(8.2 \%)$ had worse living. On the other hand, $9.8 \%$ of the farmers reported that the assistance for livelihood did not affect their living.

\section{Conclusion}

Since 2013, the rubber price has been falling for a long time which is the crisis of rubber price in the country that will be the coercion factor to make farmers adapt themselves with the decreasing incomes, previously. The pandemic COVID-19 let farmers have the ability to cope with the shock occurring quite well. The in-depth interviews found that formats of adaptation to cope with the risk of COVID-19 might be classified into 3 major formats as the following.

- Modifications of consuming format conformed to incomes and financial status of household with the following selective strategies: reducing unnecessary household expenses and luxurious things; cooking meals for household consumption; buying only needed glossary; growing food plants/home-grown vegetables around the house; and exchanging food.

- Adjustments of the financial management: most farmers had quite high debts and tried to keep the saving level; most farmers selected to extend more time to pay debts; adjusted debt structure; and increased liquidity by selling highly liquid assets such as gold, etc.

- Upsurge sources of incomes and increase the variety of production activities: some farmers had initiated plan to adjust the production system that would have more varieties of agricultural activities; farmers raised poultry, pig, bee, goat, and cow in rubber plantations to reduce the dependency of only incomes 
from rubber plantations; and farmers sought more incomes from the outside sources of agriculture such as selling goods, opening food stall, and being hired for agriculture.

\section{REFERENCES}

[1] Beamon, Benita M., "Supply Chain Design and Analysis: Models and Methods," International Journal of Production Economics 55 (3): 281-294, 1988, doi: 10.1016/s0925-527 3(98)00079-6.

[2] Malaysian Rubber Board, "A monthly publication of the Malaysian Rubber Board. DIGEST", Natural Rubber Market Review, December, 2020.

[3] Kongmanee, C \& O. Longpichai, "The perception of Risks and Risk Management Strategies of Rubber Family Farms in Southern Thailand", Parichart Journal, vol. 32, no.2, pp. 134-145, 2017.

[4] Phattarapong M; Anupong W and Chia L, "Cost Efficiency of Rubber Farmers in the Upper Northern Provinces of Thailand", International Journal of Advanced Science and Technology. Vol. 29, No.9s, pp. 4411-4418.2020.

[5] Rubber world, "Natural Rubber Types of Products", 2012. (Accessed Dec. 20, 2020).

[6] German Institute of Rubber Technology, "Rubber Research" 2010. (Accessed May 12, 2020) http://www.dikautschuk.d e/english/forsch/index.html.

[7] Wasusri, T. and A. Chaichompoo., "A Study of Logistics System for Exporting Natural Rubber from Thailand to China", 13th international Synposium on Logistics, Bangkok, Thailand, 2008.

[8] Chanpuypetch, W., and D. Kritchanchai, "Gateway Selections for Thailand Rubber Export," Asia Pacific Industrial Engineering and Management Society, Kitakyushu, Japan, 2009.

[9] Fan, S., Teng, P., Chew, P., Smith, G., \& Copeland, L., "Food system resilience and COVID- 19-Lessons from the Asian experience," Global Food Security, 28, 100501, 2021.

[10] Gregorioa, G. B., \& Ancog, R. C., "Assessing the impact of the covid-19 pandemic on agricultural production in Southeast Asia: toward transformative change in agricultural food systems," Asian Journal of Agriculture and Development, 17(1362-2020-1097), 1-13, 2020.

[11] SICHE, R., "What is the impact of COVID-19 disease on agriculture"? Scientia Agropecuaria, vol. 11, no. 1, pp. 3-6, 2020. ISSN 2077-9917. DOI 10.17268/sci.agropecu.2020. 01.00 .

[12] Hirvonen, K., Abate, G. T., \& de Brauw, A., "Survey suggests rising risk of food and nutrition insecurity in Addis Ababa, Ethiopia, as COVID-19 restrictions continue," .2020, IFPRI book chapters, 46- 49 http://databank.worldbank.org/data/reports.aspx?source $=2$ $\&$ country $=$ THA $\&$ series $=\&$ period $=[$ Accessed August 20, 2021].

[13] Laborde, D., Martin, W., Swinnen, J., \& Vos, R.," COVID-19 risks to global food security," Science, 369(6503), 500-502, 2020.

[14] IVANOV, D., "Predicting the impacts of epidemic outbreaks on global supply chains: A simulation-based analysis on the coronavirus outbreak(COVID-19/SARSCo V-2) case," Transportation Research Part E: Logistics and Transportation Review, vol. 136, pp. 101922. ISSN 1366-5545, 2020.

[15] TORERO, M., "Without food, there can be no exit from the pandemic," Nature, vol. 580, no. 7805, pp. 588-589, 2020

[16] Reardon, T., Bellemare, M.F. and Zilberman, D., "How COVID-19 may disrupt food supply chains in developing countries," IFPRI book chapters, pp.78-80, 2020

[17] Cardwell, R. and Ghazalian, P.L., "COVID-19 and International Food Assistance: Policy proposals to keep food flowing," World Development, 135, p.105059, 2020

[18] Blanco-Capia, LE., "The agricultural sector against COVID-19," Journal of the Selva Andina Biosphere, 8 (1), pp. 1-2, 2020.

[19] GALANAKIS, C.M., "The Food Systems in the Era of the Coronavirus (COVID-19) Pandemic Crisis. Foods," vol. 9, no. 4 , pp. 523, 2020.

[20] Reuben R. C.; Danladi M. A.; Saleh D. A. and Ejembi P. E., "Knowledge, Attitudes and Practices Towards Covid-19: An Epidemiological Survey in North- Central Nigeria," Journal of Community Health. Jul. 7: 1- 14, 2020. Doi: 10.1007/s10900-020-00881-1

[21] Laborde, D., Martin, W., Swinnen, J., \& Vos, R., "COVID-19 risks to global food security," Science, 369(6503), 500-502, 2020.

[22] Arndt, C., Davies, R., and Gabriel, S., "Covid-19 lockdowns, income distribution, and food security: An analysis for South Africa," Global Food Security, vol. 26, pp. 100410. ISSN 2211- 9124, 2020.

[23] Conde-Blanco, E. A., "El sistema alimentario y el Covid-19: La necesidad de prevenir otras Pandemias," Journal of the Selva Andina Biosphere, 8(1), 64-66, 2020.

[24] PU, M. and ZHONG, "Rising concerns over agricultural production as COVID-19 spreads: Lessons from China," Global Food Security, vol. 26, pp. 2020. 100409. ISSN 2211-9124.

[25] Poudel, P. B., Poudel, M. R., Gautam, A., Phuyal, S., Tiwari, C. K., Bashyal, N., \& Bashyal, S., "COVID-19 and its global impact on food and agriculture," Journal of Biology and Today's World, 9(5), 221-225, 2020.

[26] Caballero-Anthony, M., Teng, P., \& Montesclaros, J. M. L., "COVID-19 and Food Security in Asia: How Prepared are We?” NTS Insights, no.IN20-03, June 2020. 